\title{
Influence of different obturation techniques in coronal bacterial infiltration: study in
}

\section{dogs}

\author{
Influência de diferentes técnicas de obturação na infilltração bacteriana coronária: estudlo em cães
}

Influencia de diferentes técnicas de obturación en la infiltración bacteriana coronal: estudio en

perros

Received: 03/14/2021 | Reviewed: 03/21/2021 | Accept: 03/24/2021 | Published: 04/01/2021

Eloi Dezan-Júnior

ORCID: https://orcid.org/0000-0002-5699-6578 São Paulo State University, Brazil E-mail: dezan@foa.unesp.br

Carlos Roberto Emerenciano Bueno ORCID: https://orcid.org/0000-0002-1897-2823 São Paulo State University, Brazil E-mail: dentistabueno@gmail.com

Ana Maria Veiga Vasques

ORCID: https://orcid.org/0000-0002-1211-2363 São Paulo State University, Brazil

E-mail: anavvasques@hotmail.com Valdir de Souza

ORCID: https://orcid.org/0000-0003-3816-306X São Paulo State University, Brazil

E-mail: valdirdesouzaendodontia@gmail.com

Mauro Juvenal Nery

ORCID: https://orcid.org/0000-0002-4643-7780 São Paulo State University, Brazil

E-mail: mauroneryendodontia@gmail.com José Arlindo Otoboni Filho

ORCID: https://orcid.org/0000-0001-9215-1292 São Paulo State University, Brazil

E-mail: joseotoboniendodontia@gmail.com

Pedro Felício Estrada Bernabé ORCID: https://orcid.org/0000-0003-3276-9773 São Paulo State University, Brazil

E-mail: pedrobernabeendodontia@gmail.com João Eduardo Gomes-Filho

ORCID: https://orcid.org/0000-0001-5994-2287 São Paulo State University, Brazil E-mail: joao.eduardo@unesp.br

Luciano Tavares Ângelo Cintra ORCID: https://orcid.org/0000-0003-2348-7846 São Paulo State University, Brazil E-mail: luciano.cintra@unesp.br

Rogério de Castilho Jacinto

ORCID: https://orcid.org/0000-0002-2362-8920 São Paulo State University, Brazil E-mail: rogerio.castilho@unesp.br

Gustavo Sivieri-Araújo

ORCID: https://orcid.org/0000-0002-8402-7408 São Paulo State University, Brazil E-mail: gustavo.sivieri@unesp.br

Roberto Holland

ORCID: https://orcid.org/0000-0002-2191-3621 São Paulo State University, Brazil

E-mail: robertohollandendodontia@gmail.com

\begin{abstract}
The objective of this study was to evaluate, in vivo, coronal bacterial infiltration after endodontic treatment with different obturation technique. Forty-five dogs' root canals, originated from incisors and premolars, were used. The animals were intubated after general anesthesia. After local antisepsis and placement of rubber dam isolation, teeth were opened and instrumented up to a Kerr handfile \#40, followed by three obturation protocols with Endofill ${ }^{\circledR}$ :
\end{abstract}


Lateral condensation, Lateral condensation with a coronal plug of set Endofill ${ }^{\circledR}$ and Tagger hybrid technique. Access openings were not sealed and root fillings remained exposed to oral environment for 90 days. After this period, animals were euthanized and specimens were histologically processed and stained with Brown and Brenn. Dentinal tubules were evaluated with presence or absence of bacteria descriptive analysis. Bacterial infiltration was identified on root canal walls in six out of 14 root canals filled with the lateral condensation technique $(42,8 \%)$, two out of 15 canals filled with Lateral condensation with a plug of set Endofill ${ }^{\circledR}(13,3 \%)$ and in two out 13 root canals filled with the Tagger hybrid technique $(15,3 \%)$. Although the use of a coronal plug or a thermomechanical compaction technique showed less bacterial infiltration than conventional lateral condensation, none of the obturation techniques prevented bacterial infiltration to periapical area, evidencing the importance of a proper coronal seal or final restoration.

Keywords: Dental leakage; Dental pulp cavity; Endodontics; Root canal obturation.

\section{Resumo}

O objetivo deste estudo foi avaliar, in vivo, a infiltração bacteriana coronária após tratamento endodôntico com diferentes técnicas de obturação. Foram utilizados 45 canais radiculares de cães, originados de incisivos e prémolares. Os animais foram intubados após anestesia geral. Após antissepsia local e isolamento absoluto, os dentes foram acessados e instrumentados até uma lima manual K\#40, seguido de três protocolos de obturação com Endofill ${ }^{\circledR}$ : Condensação lateral, Condensação lateral com plug coronário de Endofill ${ }^{\circledR}$ endurecido e técnica híbrida de Tagger. Os acessos coronários não foram selados e as obturações permaneceram expostas ao meio bucal por 90 dias. Após esse período, os animais foram eutanasiados e os espécimes processados histologicamente e corados com Brown e Brenn. Os túbulos dentinários foram avaliados com análise descritiva da presença ou ausência de bactérias. Infiltração bacteriana foi identificada nas paredes do canal radicular em seis dos 14 canais radiculares preenchidos com a técnica de condensação lateral $(42,8 \%)$, dois dos 15 canais preenchidos com condensação lateral com um plug de Endofill ${ }^{\circledR}$ $(13,3 \%)$ e em dois de 13 canais obturados pela técnica híbrida de Tagger (15,3\%). Embora o uso do plug coronal ou da técnica de compactação termomecânica tenha demonstrado menor infiltração bacteriana do que a condensação lateral convencional, nenhuma das técnicas de obturação evitou a infiltração bacteriana na região periapical, evidenciando a importância de um selamento coronário adequado ou restauração final.

Palavras-chave: Cavidade pulpar; Endodontia; Infiltração dentária; Obturação do canal radicular.

\section{Resumen}

El objetivo de este estudio fue evaluar, in vivo, la infiltración bacteriana coronaria tras un tratamiento endodóntico con diferentes técnicas de obturación. Se utilizaron 45 conductos radiculares de perro, procedentes de incisivos y premolares. Los animales fueron intubados después de la anestesia general. Después de la antisepsia local y el aislamiento absoluto, se accedió a los dientes y se instrumentaron en una lima manual K \# 40, seguido de tres protocolos de llenado con Endofill@: condensación lateral, condensación lateral con tapón coronario Endofill@ endurecido y técnica híbrida de Tagger. Los accesos coronarios no fueron sellados y los empastes permanecieron expuestos al medio oral durante 90 días. Después de este período, los animales fueron sacrificados y las muestras procesadas histológicamente y teñidas con Brown y Brenn. Los túbulos dentinarios se evaluaron con análisis descriptivo de la presencia o ausencia de bacterias. Se identificó infiltración bacteriana en las paredes del conducto radicular en seis de los 14 conductos radiculares rellenos con la técnica de condensación lateral (42,8\%), dos de los 15 conductos rellenos de condensación lateral con un tapón Endofill® $(13,3 \%)$ y en dos de 13 canales rellenados por la técnica híbrida de Tagger (15,3\%). Aunque el uso del tapón coronal o la técnica de compactación termomecánica ha mostrado una menor infiltración bacteriana que la condensación lateral convencional, ninguna de las técnicas de obturación evitó la infiltración bacteriana en la región periapical, mostrando la importancia de un adecuado sellado coronario o restauración final.

Palabras clave: Cavidad pulpar; Endodoncia; Filtración dental; Obturación del conducto radicular.

\section{Introduction}

The objective of endodontic therapy is to prevent or heal periapical periodontitis, mainly caused by microorganisms and their by-products. However, microleakage may occur after obturation, recontaminating root canal system (Yamauchi et al. 2006, Braz Junior et al. 2021), defined as "the clinically undetectable passage of bacteria, fluids, molecules or ions between tooth and the restorative or filling material" and may be considered one of the most important risk factor for apical periodontitis in endodontically treated teeth (Muliyar et al. 2014).

Although periapical tissue is the most common affected area by endodontic disease, special attention should be directed to the coronal portion of the root canal, since an adequate coronal sealing is primordial for healing after endodontic treatment, previously associated with less inflammatory infiltrate (Yamauchi et al. 2006) or even reduction of apical 
periodontitis (Shiper et al. 2005). The recontamination of obturated root canal via coronal leakage allows bacteria to reach periapical tissues, and can occur in cases where obturation is exposed to the oral environment, usually found in: (a) loss, fracture or failure of restoration; (b) recurrent caries; (c) delay in restoration, with infiltration through temporary restorative material; and (d) during the restorative procedure (Khayat et al. 1993). In addition, near 30\% of endodontic failures is related leakage around the filling material, indicating this as one of the most common possible cause (Song et al. 2011).

The obturation technique is of paramount importance, since in vitro bacterial permeability of gutta-percha/sealer was observed (Libonati et al. 2018), evidencing the need for adequate seal ability of the filling materials. Because the clinically significant saliva penetration, once obturation is exposed to oral environment for even 20 days, bacteria (Torabinejad et al. 1990) or endotoxin (Trope et al. 1995) may move through a totally obturated root canal. Microorganisms in the oral fluid may infiltrate through the dentin/temporary restorative sealer interface, highlighting the importance of restorative procedures, which may avoid marginal microleakage (Nakamura et al. 2006), leading authors to state that the integrity of coronal restoration is as important as the obturation quality (Ray \& Trope 1995, Tronstad et al. 2000).

In view of root canal contamination or recontamination, which may jeopardize endodontic treatment, the success is achieved after definitive restoration. Thus, it's important to understand and evidence, in vivo, factors that may influence coronal infiltration, especially if different obturation techniques can prevent or decrease bacterial infiltration. Therefore, this study assessed in vivo the influence of different obturation techniques in coronal bacterial leakage.

\section{Methodology}

This research was approved before the beginning of the experiment by the institutional Ethics Committee on the Use of Animals at Araçatuba School of Dentistry (UNESP/FOA).

\section{Animals}

The sample size was calculated based on previous studies (Barbosa et al. 2003, Holland et al. 2007a, Holland et al. 2007b, Borlina et al. 2010), with additional elements per group, considering possible loss of specimens during experimental period or histologic processing. From each dog, maxillary incisors (single root) and both maxillary and mandibular premolars (two root canal each) were selected (Holland et al. 2007a, Borlina et al. 2010), totaling 45 root canals.

The animals were kept in a clean and ventilated vivarium inside the University and received vaccines and standard medicines before and during the experimental period. The animals received balanced food and water ad libitum, weekly inspected.

\section{In vivo procedures}

Animals were pre-anesthetized with Acine (Xylazine Bayer S/A - Veterinary Products - Ind. Brazil; 0,11mg/kg) and, 5 minutes later, Ketamine 50 (Parke - Davis - Achê Pharmaceutical Laboratories S/A; 15mg/kg), was injected intramuscularly 15 minutes before surgery, to make the animals docile and receptive to anesthesia.

General anesthesia was obtained by intravenous injection of 3\% Nembutal Sodium (Hypnol - Cristália Produtos Químicos Farmacêuticos Ltda; dosage $1 \mathrm{ml} / \mathrm{kg}$ ), supplemented when necessary. The animals were then intubated with an optic fiber laryngoscope (Ref. 400, Kole Equimed) for the placement of an endotracheal catheter No. 28 (Rusch with Cuff, Federal Rep., Germany), to avoid respiratory problems and to allow artificial ventilation in case of respiratory failure. Throughout the operative period, and approximately 30 minutes after conclusion, the animals received intravenous glucose solution at $5 \%$ (Laboratory J.P. - Indústria Farmacêutica S.A.). 
Before endodontic intervention, diagnostic radiographs of the teeth to be operated were taken, in order to observe conditions of roots normality, as well as bone support.

The teeth received prophylaxis with a rubber cup/pumice and rubber dam was placed, followed by antisepsis of the operative field with $0.3 \%$ polyvinylpyrrolidone-iodine solution. Coronal access was obtained with a \#1090 cylindrical diamond bur (KG Sorensen, Barueri, Brazil) in refrigerated high speed rotation and pulp tissue was extirpated with a \#15 K-file (Dentsply/Maillefer Instruments, Ballaigues, Switzerland). Instrumentation was performed with the crown-down technique (Barbosa et al. 2003, Holland et al. 2007a, Holland et al. 2007b, Borlina et al. 2010): After orifice opener $\mathrm{N}^{\circ}$ 1, 2 and 3, cervical and middle biomechanical preparation was achieved with Gates-Glidden drills 3, 2, 1 and manual instrumentation up to a size $40 \mathrm{~K}$-file (Dentsply/ Maillefer) at the limit of the cementodentinal junction (CDJ), determined by tactile sense and confirmed by radiographic images. Throughout the biomechanical preparation, roots were irrigated with $3 \mathrm{~mL}$ of saline, at each change of file (Holland et al. 1999, Holland et al. 2007b, Fonseca et al. 2020).

After instrumentation, root canals were irrigated, aspirated and flooded with 17\% EDTA solution for 3 minutes for smear layer removal. Then, canals were irrigated with saline and dried with sterile paper points. The root canals were obturated with a main gutta-percha cone calibrated to a \#40 loaded with Endofill ${ }^{\circledR}$ sealer and accessory guta-percha at the CDJ limit, forming the three experimental obturation groups $(n=15)$, as follows: group 1: lateral condensation; group 2: lateral condensation with coronal plug of set Endofill ${ }^{\circledR}$; group 3: Tagger hybrid technique. Obturation excess was removed with a heated plugger at coronal level, and the remaining filling material was vertically condensed. Then, after cleaning the pulp chamber, coronal openings were not sealed, leaving the obturated roots exposed to oral environment. Radiographs were taken to evaluate obturation homogeneity and quality.

\section{Histologic analysis}

After 90 days exposing obturated roots to oral environment, animals were euthanized by anesthetic overdose. The maxilla and mandibles containing the root-filled samples were removed, fixed in 10\% neutral-buffered formalin for 72 hours and demineralized in 20\% EDTA solution. After dehydration and diaphanization, segments were embedded in paraffin. Serial $6 \mu \mathrm{m}$ thick longitudinal sections were obtained from each specimen and stained with Brown and Brenn technique for microscopic evaluation, which allows observation of $\mathrm{Gram}^{+}$(as Nocardia and Actinomyces filaments stains in blue) and Gram (as nuclei stains in red) and additional tissue elements (yellow staining) (Brown \& Brenn 1931, Holland et al 2007a, Borlina et al. 2010, Gomes-Filho et al. 2013).

\section{Results}

\section{Descriptive Analyses}

As the Brown \& Brenn technique was used to observe bacterial presence, a descriptive analysis (Koche 2011) was chosen to classify regarding the presence or absence of bacterial infiltration.

During laboratory process, one sample from Lateral Condensation Group and two samples from Tagger Hybrid group were discarded. No sample loss occurred in Lateral Condensation with a plug of set Endofill ${ }^{\circledR}$ group, totaling 42 analyzed samples.

All specimens showed food residues and debris in the coronal pulp chamber and near the canal entrance (Figure 1). 
Figure 1. Dog's premolar with coronal opening exposed to the oral environment for 90 days, evidencing presence of food residues and debris in pulp chamber and canal entrance (200x; Brown \& Brenn staining).

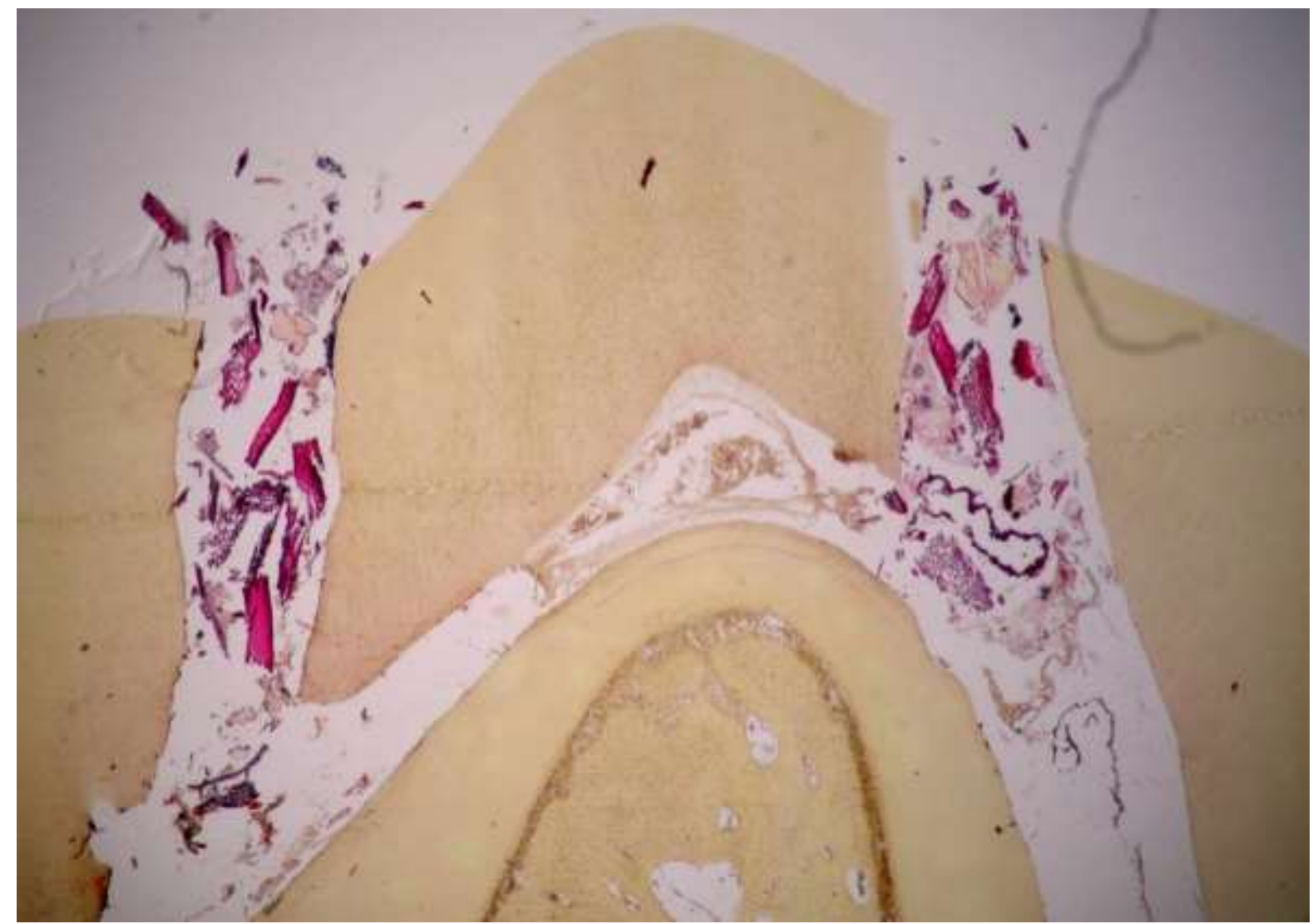

Source: Authors.

\section{Lateral Condensation Group}

The specimens analyzed in this group consisted of three incisors and six premolars totalizing 14 root canals.

Bacterial infiltration was observed in the interior of six canals until near the foramen (Table 1). Gram positive and negative bacteria were present in root canal walls, until the apical third, colonizing dentinal tubules (Figure 2). 
Figure 2. Lateral condensation group in (A): the main canal with a lateral foramen exit surrounded by periodontal ligament and the analysis area (100x, Brown \& Brenn staining); (B) Presence of bacterial infiltration colonizing dentinal tubules (400x, Brown \& Brenn staining).

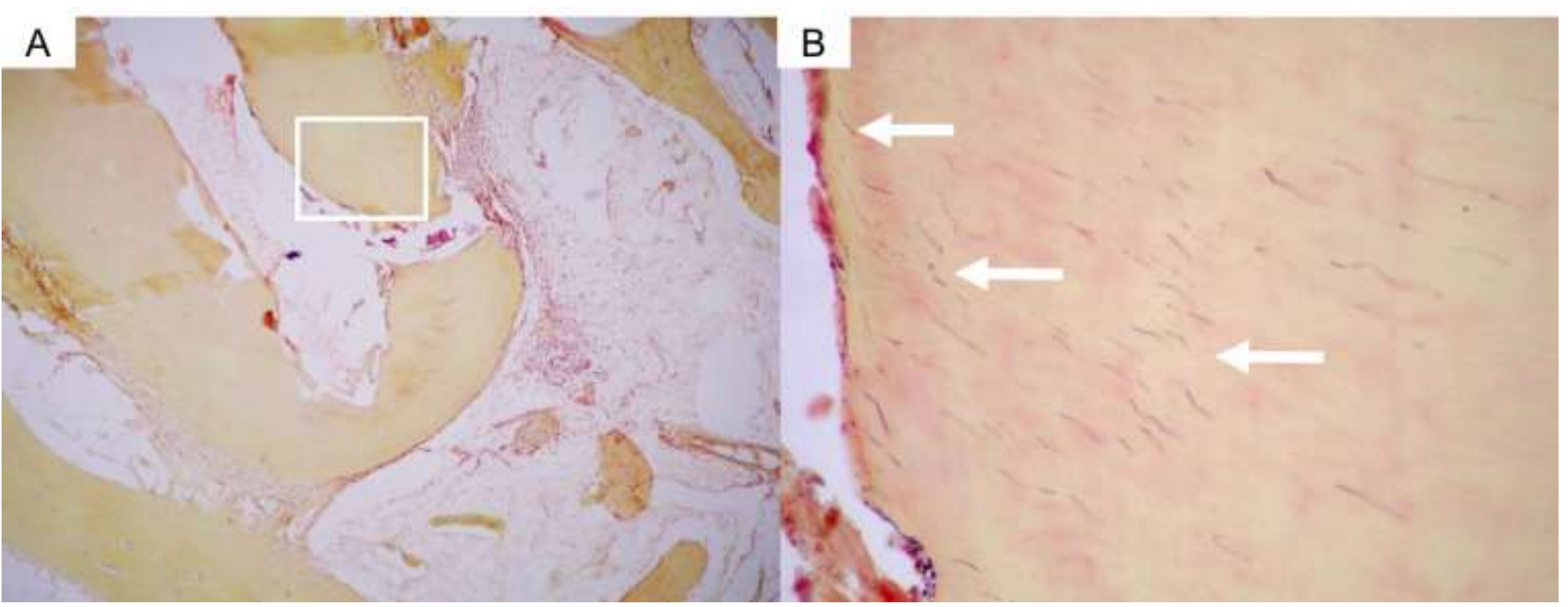

Source: Authors.

\section{Lateral Condensation with a plug of set Endofill ${ }^{\circledR}$ group}

The analyzed specimens consisted of three incisors and six premolars totaling 15 root canals. Under microscope observation, two specimens showed Gram positive and negative bacteria infiltration in the dentinal wall (Table 1), near apical ramification, also invading dentinal tubules. Tooth apex showed thickened periodontal ligament and inflammatory cell infiltrate.

The presence of bacteria Gram positive and Gram negative was observed adhered to the external root dentinal wall with mild inflammatory infiltrate (Figure 3).

In one incisor, bacterial infiltration throughout the entire canal and invasion of dentinal tubules near apical area was also observed, as the presence of an inflammatory infiltrate within the periodontium. 
Figure 3. Lateral Condensation with a plug of set Endofill ${ }^{\circledR}$ group with Brown \& Brenn staining: (A) periapical area with the main canal and a lateral foramen exit showing the analysis area under 100x; a magnification of 400x (B) evidences the presence of bacteria (white arrow) inside dentinal tubules and adhered to the main canal wall.

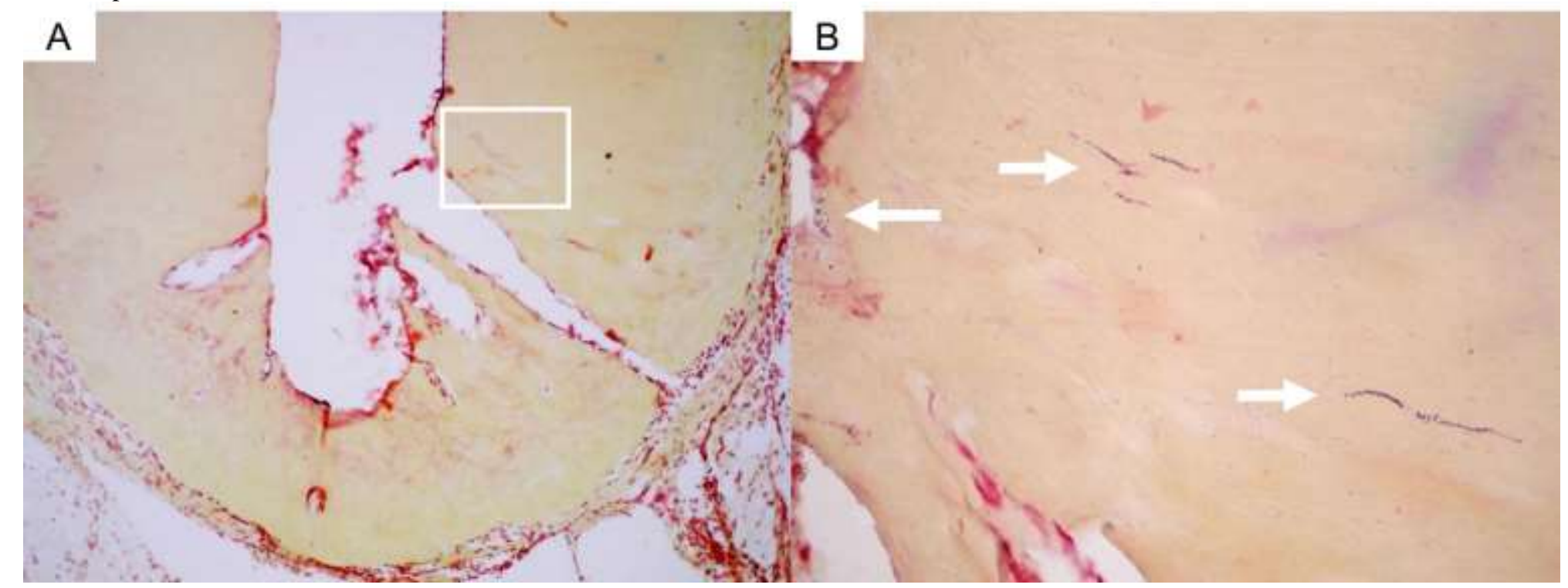

Source: Authors.

\section{Tagger Hybrid technique group}

In this group three premolars and seven incisors were analyzed, totaling 13 root canals, in which eight samples showed no inflammation.

Two specimens showed elevated bacterial infiltration throughout the entire obturated canal (Table 1), observed inside dentinal tubules from the coronal area and extending to apical, which presented greater density of contaminated dentinal tubules, populated by Gram positive and negative bacteria. Inflammatory infiltrate could also be observed at the foramen area (Figure 4). 
Figure 4. The Tagger hybrid group shows indication of extruded obturation over the foramen and the analysis area in $\mathbf{A}$ (100x); In B: a higher magnification shows bacterial colonization (white arrow) inside dentinal tubules in periapical area (400x, Brown \& Brenn staining).

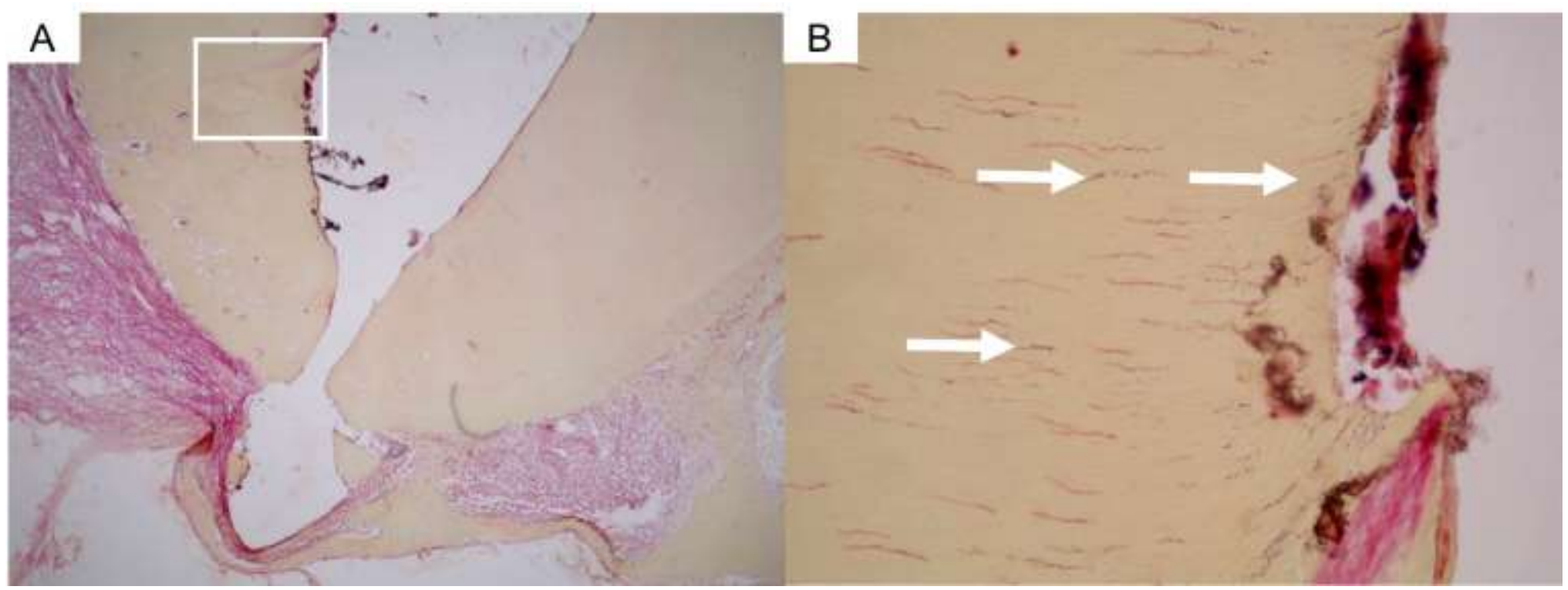

Source: Authors.

In one of the samples, even with extruded obturating material, microorganisms populated apical dentinal tubules, delta area and were also observed in the apical periodontal ligament, next to the extruded material. Another sample, with inflammation and thick periodontal ligament, Gram positive and negative bacteria were observed at the inner wall of the canal until apical ramification, but not inside dentinal tubules.

From 42 analyzed samples, 10 presented bacteria inside dentinal tubules, corresponding to $23,8 \%$ from the total (Table 1).

Table 1. Experimental groups showing the percentage of contaminated samples.

\begin{tabular}{r|lcc} 
Experimental Group & $\boldsymbol{n}$ & Contaminated samples & $\%$ \\
\hline Lateral Condensation & 14 & 6 & 42,8 \\
Lateral condensation + plug & 15 & 2 & 13,3 \\
Tagger hybrid & 13 & 2 & 15,3 \\
total & 42 & 10 & 23,8
\end{tabular}

\section{Discussion}

Coronal infiltration by microorganisms through obturated root canal has been previously investigated, demonstrating in vitro the recontamination possibility (Oliveira et al. 2013). However, in vivo studies are necessary to represent what occurs in the oral cavity. Thus, the present study evaluated, in vivo, the influence of two different obturation techniques on bacterial infiltration and the addition of a protection plug, when exposed to oral environment without coronal sealing for 90 days.

According to Friedman et al. (1997), the dog model for in vivo researches was developed to overcome limitations of in vitro studies, since allows the evaluation of endodontic materials within a clinical/oral environment. Based on this fact, the dog model has been used for several years (Holland et al. 1971, Holland et al. 1999, Souza et al. 2006, Holland et al. 2007a, Holland et al. 2007b, Shipper et al. 2005, Yamauchi et al. 2006, Borlina et al. 2010, Gomes-Filho et al. 2013). 
As previously demonstrated by Khayat et al. (1993), coronal bacteria infiltration along with its metabolites can penetrate the entire extent of an obturated root canal in shorter periods than the experimental ninety days used in the present study. Infiltration was previously observed in vitro after four (Khayat et al. 1993), six (Trope et al. 1995), ten (Chailertvanitkul et al. 1997a), seventeen (Chailertvanitkul et al. 1997b) or nineteen days (Torabinejad et al. 1990).

It is also important to emphasize that endotoxin penetration is faster than bacterial penetration (Chow et al. 1993, Trope et al. 1995). However, a previous study demonstrated that obturation technique may hinder infiltration. Carratù et al. (2002) evaluated in vitro the lateral condensation obturation technique with a eugenol/zinc-oxide sealer and observed that, despite no endotoxin was present in samples, all specimens had bacterial infiltration after 13 days.

Song et al. (2011) analyzed via an operating microscope during endodontic microsurgery, the cause of failure in endodontic nonsurgical treatment. The authors analyzed 493 teeth, and observed that perceived leakage around filling material was the most common possible cause for endodontic failure (30.4\%), followed by a missing canal (19.7\%), underfilling (14.2\%), anatomical complexity (8.7\%), overfilling (3.0\%), iatrogenic problems $(2.8 \%)$, apical calculus (1.8\%) and cracks (1.2\%), emphasizing the importance of the coronal sealing/restoration and the possibility of root canal re-contamination by oral bacteria, a consideration also in accordance with a recent study by Braz Junior et al. (2021).

However, the average time of coronal infiltration, usually evaluated in vitro, varies due to the different methodologies and materials, as opposed to in vivo studies, which may be influenced by the animal's diet, dental anatomy, materials and technique, among other variables. Regarding the postoperative period in the present study, after ninety days, initial inflammation after endodontic treatment due to mechanical trauma and initial reaction to the sealer would have been overcome, converting the initial acute inflammation into chronic. However, Zmener et al. (2010) demonstrated in subcutaneous tissue of rats that even after 90 days, a zinc oxide and eugenol sealer may induce a severe inflammation.

Although sodium hypochlorite $(\mathrm{NaOCl})$ is the most commonly used irrigating solution for root canal therapy (Slaus \& Bottenberg 2002, Clarkson et al. 2003, Nascimento et al. 2021), the use of an irrigant with antibacterial properties could interfere with residual action for undetermined time on microorganisms that would penetrate the area subjected to analysis. For this reason, the root canals were irrigated with saline (Fonseca et al. 2020), corroborating a previous methodology (Holland et al. 2000). The EDTA solution was used in static protocol, prior to obturation in order to chelate calcium, opening dentinal tubules to enhance sealer penetration (Bueno et al. 2019).

The endodontic sealer used for obturation in the present study was a zinc oxide-eugenol-based sealer. Since the research aimed to assess the presence of bacteria inside dentinal tubules after different obturation techniques, sealers with low antibacterial effect would be more appropriate, although after 90 days, no antimicrobial activity would be expected. According to Savioli et al et al. (2006), eugenol shows antimicrobial activity, and when incorporated to an endodontic sealer, shows inhibition bacterial zones in in vitro study (Monajemzadeh et al. 2017, Dragland et al. 2019). However, Wang et al. (2014) showed, via confocal laser scanning microscopy, a weaker antibacterial effect of ZOE sealer than AH Plus, corroborating posterior results found by Singh et al. (2016) and Dalmia et al. (2018).

With respect to the results for the different obturation techniques, all groups showed bacterial infiltration. The lateral condensation group was chosen since is a commonly used technique (Leduc \& Fishelberg 2003), with elevated sealer penetration (Macedo et al. 2017), mainly due to the pressure promoted by the gutta-percha cones against dentin walls, increasing interaction between sealer and root dentin (Hatton et al. 1988). Nevertheless, our results showed the highest bacterial infiltration in the Lateral Condensation group. The group with a plug of set Endofill sealer and Tagger's hybrid technique group showed reduced infiltration, but not prevented. This is in accordance with previous studies, evidencing that the use of a protection plug over the obturation may aid the healing, delaying the bacterial infiltration (Holland et al. 2007a, Yamauchi et al. 2006), while Tagger hybrid's technique provides better homogeneity and apical sealing than lateral 
condensation (Fracassi et al. 2013, Saberi et al. 2017).

Based on the results, we hypothesized that a possible leakage in the obturation-dentin interface may occur with lateral condensation group, which is reduced in the Tagger hybrid technique, since obturation becomes a more homogenous single mass, corroborating an ex vivo study in which authors showed that single cone technique (with tapered cone) and hybrid technique are more effective in prevention of coronal leakage than lateral condensation technique (Saberi et al. 2017). In addition, in vitro studies with thermoplasticized/warm/flow gutta percha techniques also showed bacterial infiltration (Libonati et al. 2018, Lone et al. 2018, Prithviraj et al. 2020).

Regarding the staining technique, while the Brown and Brenn staining may present limitations in the identification of microorganisms due to the decalcification process (Wijnbergen \& Van Mullem 1987), this technique has been previously used to assess the presence of microorganism (Holland et al 2007a, Borlina et al. 2010), leading our results to suggest that most of the bacteria contained in the specimens of this research may not have been detected or even may be eliminated during laboratory processing.

A systematic review conducted by Gillen et al. (2011) showed that healing of apical periodontitis increase with both adequate root canal therapy and adequate restorative treatment. Therefore, it's preferable to perform a permanent restoration immediately after root canal treatment than using a provisional restoration (Lynch et al. 2004), which may depend even of a correct thickness to decrease bacterial infiltration (Shanmugam et al. 2020), while waiting for the resolution of apical periodontitis. It's also important to emphasize that even root canals with an intracanal post but without a prosthetic crown can be recontaminated when exposed to human saliva in a short period of time and the exposure of endodontically treated teeth to the oral environment may indicate endodontic retreatment (Tronstad et al. 2000, Oliveira et al. 2013, Mohajerfar et al. 2019).

\section{Conclusion}

Coronal bacterial infiltration was evidenced in root canals obturated regardless the technique when exposed to the oral environment for 90 days. When present, bacteria inside the canals and apical dentinal tubules may negatively interfere with the apical repair process. The endodontic treatment should only be considered concluded when the tooth is completely restored.

Further in vivo studies are encouraged to provide a better comprehension of bacterial infiltration via coronal leakage in oral environment with different obturation techniques such as single cone and thermoplasticized techniques/continuous wave of obturation, besides the use of different sealers, like resinous or bioceramic endodontic sealers.

\section{References}

Barbosa, H.G., Holland, R., de Souza V., et al. (2003). Healing process of dog teeth after post space preparation and exposition of the filling material to the oral environment. Braz Dent J, 14:103-108.

Borlina, S.C., Souza, V., Holland, R., \& Murata, S. S., et al. (2010). Influence of apical foramen widening and sealer on the healing of chronic periapical lesions induced in dogs' teeth. Oral Surg Oral Med Oral Pathol Oral Radiol Endod, 109:932-940.

Braz Junior, R., Albuquerque, M.S. de., Sena, K.X. da F.R. de., et al. (2021). Evaluation of cervical microleakage by Enterococcus faecalis in endodontically treated teeth sealed with composite resins. Res Soc Dev, 9: e3599108356.

Brown, J. H. \& Brenn, L. (1931). A method for the differential staining of Gram-positive and Gram-negative bacteria in tissue sections. Bull Johns Hopkins Hosp, 48:69-73.

Bueno, C. R. E., Cury, M. T. S., Vasques, A. M. V., et al. (2019). Cleaning effectiveness of a nickel-titanium ultrasonic tip in ultrasonically activated irrigation: a SEM study. Braz Oral Res, 33: e017.

Carratù, P., Amato, M., Riccitiello, F., \& Rengo, S. (2002). Evaluation of leakage of bacteria and endotoxins in teeth treated endodontically by two different techniques. J Endod, 28:272-5.

Chailertvanitkul, P., Saunders, W. P., \& Mackenzie, D. (1997a). Coronal leakage in teeth root-filled with two different sealers after long-term storage. Endod Dent Traumatol, 13: 82-7. 
Chailertvanitkul, P., Saunders, W. P., \& Mackenzie, D. (1997b). Coronal leakage of obturated root canals after long-term storage using a polimicrobial marker. J Endod, 23: 610-13.

Chow, E., Trope, M., \& Nissan, R. (1993). In vitro endotoxin penetration of coronally unsealed endodontically treated teeth. J Endod, Abstract 8; $19: 187$.

Clarkson, R. M., Podlich, H. M., Savage, N. W., \& Moule, A. J. (2003). A survey of sodium hypochlorite use by general dental practitioners and endodontists in Australia. Aust Dent J, 48:20-6.

Dalmia, S., Gaikwad, A., Samuel, R., Aher, G., Gulve, M., \& Kolhe, S. (2018). Antimicrobial Efficacy of Different Endodontic Sealers against Enterococcus faecalis: An In vitro Study. J Int Soc Prev Community Dent, 8:104-109.

Dragland, I. S., Wellendorf, H., Kopperud, H., et al. (2019). Investigation on the antimicrobial activity of chitosan-modified zinc oxide-eugenol cement. Biomater Investig Dent, 6(1), 99-106.

Fonseca, L. de A., Cangussu, R. A., Oliveira, A. S. de, et al. (2020). Comparison of endodontic disinfection of primary teeth root canals using rotary and reciprocating system: An in vitro study. Res Soc Dev, 9(8): e457985882.

Fracassi, L. D., Ferraz, E. G., Albergaria, S. J., Veeck, E. B., Costa, N. P., Sarmento, V. A. (2013). Evaluation of the quality of different endodontic obturation techniques by digital radiography. Clin Oral Invest, 17:97-103.

Friedman, S., Torneck, C. D., Komorowski, R., Ouzounian, Z., Syrtash, P., \& Kaufman, A. (1997). In vivo model for assessing the functional efficacy of endodontic filling materials and techniques. J Endod, 23:557-561.

Gillen, B. M., Looney, S. W., Gu, L. S., et al. (2011). Impact of the quality of coronal restoration versus the quality of root canal fillings on success of root canal treatment: a systematic review and meta-analysis. J Endod, 37:895-902.

Gomes-Filho, J. E., Watanabe, S., Cintra, L. T. A., Nery, M. J., Dezan-Junior, E., Queiroz, I. O. A., Lodi, C. S., \& Basso, M. D. (2013). Effect of MTA-based sealer on the healing of periapical lesions. J App Oral Sci, 21:235-242.

Hatton, J. F., Ferrillo, P. J., Wagner, G., \& Stewart, P. (1988). The effect of condensation pressure on the apical seal. J Endod, 14:305-308.

Holland, R., Mazuqueli, L., Souza, V., Murata, S. S., Dezan-Júnior, E., \& Suzuki, P. (2007b). Influence of the Type of Vehicle and Limit of Obturation on Apical and Periapical Tissue Response in Dogs' Teeth After Root Canal Filling with Mineral Trioxide Aggregate. J Endod, 33:693-697.

Holland, R., Souza, V., Nery, M. J., Otoboni Filho, J. A., Bernabé, P. F. E., \& Dezan Junior, E. (1999). Reaction of dog's teeth to root canal filling with mineral trioxide aggregate or a glass ionomer sealer. J Endod, 25:728 -30.

Holland, R., Souza, V., Tagliavini, R. L., \& Milanezi, L. A. (1971). Healing process of teeth with open apices: histological study. Bull Tokyo dent Coll, 12:333-38.

Holland, R., Manne, L. N., Souza, V., Murata, S. S., \& Dezan-Junior, E. (2007a). Periapical Tissue Healing after Post Space Preparation with or without Use of a Protection Plug and Root Canal Exposure to the Oral Environment. Study in Dogs. Braz Dent J, 18:281-8.

Holland, R., Cruz, A. C., Souza, V., Nery, M. J., Bernabé, P. F. E., Otoboni-Filho, J. A., \& Dezan-Júnior, E. (2000). Comportamiento de los tejidos periapicales frente a la exposición de la obturación endodôntica el medio oral. Estudio histológico en dientes de peros. Endodoncia, 18:99-108.

Khayat, A., Lee, S. J., \& Torabinejad, M. (1993). Human Saliva Penetration of Coronally Unsealed Obturated Root Canals. J Endod, 19:458-61.

Koche, J. C. (2011). Fundamentos de metodologia científica: teoria da ciência e iniciação à pesquisa. Vozes:182 p

Leduc, J., \& Fishelberg, G. (2003). Endodontic obturation: a review. Gen Dent, 51:232-233.

Libonati, A., Di Taranto V., D`Agostini, C., Santoro, M. M., Di Carlo, D., Ombres, D., Gallusi, G., Favalli, C., Marzo, G., \& Campanella, V. (2018). Comparison of Coronal Leakage of Different Root Canal Filling Techniques: An Ex Vivo Study. J Biol Regul Homeost Agents, $32: 397-405$.

Lone, M. M., Khan, F. R., \& Lone, M. A. (2018). Evaluation of Microleakage in Single-Rooted Teeth Obturated with Thermoplasticized Gutta-Percha Using Various Endodontic Sealers: An In-Vitro Study. J Coll Physicians Surg Pak, 28(5): 339-343.

Macedo, L. M. D., Silva-Sousa, Y., Silva, S. R. C., Baratto, S. S. P., Baratto-Filho, F., Rached-Júnior, F. J. A. (2017). Influence of Root Canal Filling Techniques on Sealer Penetration and Bond Strength to Dentin. Braz Dent J, 28:380-4.

Mohajerfar, M., Nadizadeh, K., Hooshmand, T., et al. (2019). Coronal Microleakage of Teeth Restored with Cast Posts and Cores Cemented with Four Different Luting Agents after Thermocycling. J Prosthodont, 28(1): e332-e336.

Monajemzadeh, A., Ahmadi Asoor, S., Aslani, S., \& Sadeghi-Nejad, B. (2017). In vitro antimicrobial effect of different root canal sealers against oral pathogens. Curr Med Mycol, 3:7-12.

Muliyar, S., Shameem, K. A., Thankachan, R. P., Francis, P. G., Jayapalan, C. S., \& Hafiz, K. A. (2014). Microleakage in endodontics. J Int Oral Health, 6:99-104.

Nakamura, D. H., Garcia, R. B., Bramante, C. M., Moraes, I. G., \& Bernadineli, N. (2006). Sealing Ability of Cements In Root Canals Prepared For Intraradicular Posts. J Appl Oral Sci, 14:224-7.

Nascimento, W. M., Limoeiro, A. G. da S., Moraes, M. M., et al. (2021). Reduction in Enteroccocus faecalis counts produced by three file systems in severely curved canals. Res Soc Dev, 10(2): e58910212956.

Oliveira, S. G. D., Gomes, D. J., Costa, M. H. N., Sousa, E. R., \& Lund, R. G. (2013). Coronal microleakage of endodontically treated teeth with intracanal post exposed to fresh human saliva. J Appl Oral Sci, 21:403-8. 
Research, Society and Development, v. 10, n. 4, e11010413884, 2021

(CC BY 4.0) | ISSN 2525-3409 | DOI: http://dx.doi.org/10.33448/rsd-v10i4.13884

Prithviraj, K. J., Sreegowri, Manjunatha, R. K., Horatti, P., Rao, N., \& Gokul, S. (2020). In Vitro comparison of the microbial leakage of obturation systems: Epiphany with resilon, guttaflow, and ah plus with gutta percha. Indian J Dent Res, 31(1): 37-41.

Ray, H. A., \& Trope, M. (1995). Periapical Status of Endodontically Treated Teeth In Relation To The Technical Quality Of The Root Filling And The Coronal Restoration. Int Endod J, 28:12-8.

Savioli, R. N., Pecora, J. D., Mian, H., \& Ito, I. Y. (2006). Evaluation of the antimicrobial activity of each component in Grossman's sealer. Braz Oral Res, 20:127-131.

Shanmugam, S., PradeepKumar, A. R., Abbott, P. V., et al. (2020). Coronal Bacterial Penetration after 7 days in class II endodontic access cavities restored with two temporary restorations: A Randomised Clinical Trial. Aust Endod J, 46(3): 358-364.

Shipper, G., Teixeira, F. B., Arnold, R. R., \& Trope, M. (2005). Periapical inflammation after coronal microbial inoculation of dog roots filled with guttapercha or resilon. J Endod, 31:91-6.

Singh, G., Gupta, I., Elshamy, F. M. M., Boreak, N., \& Homeida, H. E. (2016). In vitro comparison of antibacterial properties of bioceramic-based sealer, resin-based sealer and zinc oxide eugenol based sealer and two mineral trioxide aggregates. Eur J Dent, 10:366-369.

Slaus, G., Bottenberg, P. (2002). A survey of endodontic practice amongst Flemish dentists. Int Endod J, 35:759-67.

Song, M., Kim, H. C., Lee, W., \& Kim, E. (2011). Analysis of the cause of failure in nonsurgical endodontic treatment by microscopic inspection during endodontic microsurgery. J Endod, 37:1516-1519.

Souza, R. S., Gandini-Junior, L. G., Souza, V., Holland, R., \& Dezan-Junior, E. (2006). Influence of Orthodontic Dental Movement on the Healing Process of Teeth with Periapical Lesions. J Endod, 32:115-119.

Torabinejad, M., Ung, B., \& Kettering, J. D. (1990). In Vitro Bacterial Penetration of Coronally Unsealed Endodontically Treated Teeth. J Endod, 16:566-9.

Tronstad, L., Asbjornsen, K., Doving, L., Pedersen, I., \& Eriksen, H. M. (2000). Influence of Coronal Restorations on The Periapical Health of Endodontically Treated Teeth. Endod Dent Traumatol, 16:218 -21.

Trope, M., Chow, E., \& Nissan, R. (1995). In vitro endotoxin penetration of coronally unsealed endodontically treated teeth. Endod Dent Traumatol, 11:90-4.

Wang, Z., Shen, Y., \& Haapasalo, M. (2014). Dentin extends the antibacterial effect of endodontic sealers against Enterococcus faecalis biofilms. $J$ Endod, 40:505-508.

Wijnbergen, M., \& Van Mullem, P. J. (1987). Effect of histological decalcifying agents on number and stainability of gram-positive bacteria. $J$ Dent Res, 66:1029-1031.

Yamauchi, S., Shipper, G., Buttke, T., Yamauchi, M., \& Trope, M. (2006). Effect of Orifice Plugs On Periapical Inflammation in Dogs. J Endod, $32: 524$-526.

Zmener, O., Pameijer, C. H., Kokubu, G. A., \& Grana, D. R. (2010). Subcutaneous Connective Tissue Reaction to Methacrylate Resin-based and Zinc Oxide and Eugenol Sealers. $J$ Endod, 36:1574-1579. 